\title{
Türkiye, Çin, ABD, Fransa Sağlık Sistemleri ve COVID-19 Politikaları
}

\author{
Turkey, China, USA, France Health Systems and COVID-19 Policies
}

\section{Abdurrahman Yunus SARIYILDIZ1 ${ }^{1}$, Mehmet Talha PAȘAOĞLU², Merve Ebrar YILMAZ}

\section{ÖZ}

COVID-19 pandemisi tüm dünyada ülkelerin sağlık sistemleri ve politikalarını etkilemiş ve etkilemeye de devam etmektedir. Küresel bir salgın olarak COVID19 hem sağlık politikalarının uygulanabilirliğini hem de sağlık hizmetlerini yeniden gözden geçirme ve yeni politikalara geçiş imkânı sunmaktadır. Bu çalışmada, Türkiye, Çin, ABD ve Fransa'nın sağlık sistemleri ve politikalarının COVID-19 bağlamında değerlendirilip geliştirilebilecek hususların belirlenmesi amaçlanmıştır ve her ülkenin sağlık sistemi ve politikaları ana hatları ile incelenmiş, sağlık sistemleri, bütün vatandaşlarının sağlık güvencesine sahip olmaları ve sağlık hizmetine ulaşabilmesi çerçevesinde analiz edilmiştir. Çin, Fransa ve Türkiye'deki kapsayıcı sağlık güvencesi COVID-19 pandemisi ile etkin mücadelede genel anlamda yeterli görülmüştür. ABD’de ise sağlık güvencesinden yoksun olan nüfusun çokluğu nedeniyle, kapsayıcılığın yeterli seviyede olmadığ 1 vurgulanabilir. Bu küresel salgının, ülkelerin sadece sağlık sistemlerini etkilemediği, aynı zamanda toplumsal hayatı ve ekonomiyi de etkilediği göz önüne alındığında, ilgili ülkeler gerekli önlemleri alma yolunda çeşitli adımlar atmıştır. Sağlık sisteminin yeniden gözden geçirilmesine sebebiyet veren COVID19 pandemisi devlet düzeyinde yönetişim ve liderlik yönüyle de ön plana çıkmıştır. Bu çerçevede merkezi yönetim ile yerel otoriteler birbiriyle uyumlu politika izledikleri sürece salgınla mücadelede başarılı olmuş, nitekim Fransa'da iki otorite arasındaki uyuşmazlıklar COVID-19 politikalarının yetersiz ve etkisiz kalmasına sebep olmuştur. COVID-19 pandemisi, sağlığın sadece sunulan hizmetlerin kapsayıcılığı ve hizmetlere ulaşım olarak değerlendirilemeyeceği, hem sosyo-ekonomik hem de birtakım toplumsal faktörler ile geliştirilmesi gerektiğini hatırlatmıştır.

Anahtar Kelimeler: COVID-19 pandemisi, Sağlık politikaları, Sağlık sistemleri
The COVID-19 pandemic affected and continues to affect the health systems and health policies of countries all over the world. As a global pandemic, COVID-19 offers opportunities both to review the applicability of health policies, to review healthcare services and for transition to new policies. In this study, Turkey, China, US, and France's health systems and policies were evaluated in order to determine the issues to be developed in the context of COVID-19. The health system and policies of each country were evaluated with the main lines; health systems were analyzed within the framework that all citizens have health insurance and have access to health services. Inclusive health insurance in Turkey, China and France seems satisfactory in general, in the sense of combating effectively the pandemic. In the USA, on the other hand, it can be emphasized that the inclusion is not at a sufficient level due to the high population of the population lacking health insurance. Considering that this global epidemic not only affects the health systems of countries, but also affects the social life and economy, the relevant countries have taken various steps to take the necessary measures. The COVID-19 pandemic which led to the reconsideration of the health system, came to the fore with its governance and leadership at the state level. In this context, as long as the central government and local authorities follow a compatible policy, they have been successful in combating the epidemic. As a matter of fact, the disputes between the two authorities in France have caused COVID-19 policies to remain inadequate and ineffective. The COVID-19 pandemic has reminded that health cannot be evaluated only as the inclusiveness and accessibility of the services provided, but must be improved by both socioeconomic and social factors.

Keywosds: COVID-19 pandemic, Health policies, Health Systems

\footnotetext{
${ }^{1}$ Dr. Öğr. Üyesi, Abdurrahman Yunus SARIYILDIZ, Sağlık Yönetimi, Samsun Üniversitesi, yunus.sariyildiz@samsun.edu.tr, ORCID: 00000003-2526-5016

${ }^{2}$ Dr. Öğr. Üyesi, Mehmet Talha PAŞAOĞLU, Siyaset Bilimi, Samsun Üniversitesi, talha.pasaoglu@ samsun.edu.tr, ORCID: 0000-00033427-0730

${ }^{3}$ Arş. Gör., Merve Ebrar YILMAZ, Sağlık Yönetimi, Samsun Üniversitesi, ebrar.yilmaz@ samsun.edu.tr, ORCID: 0000002-57262381
} 


\section{GíRiş}

Herhangi bir hizmetin kamu ve özel kesim tarafından verilip verilemeyeceği, ne kadarının kamu ne kadarının özel sektörce verileceğine karar vermek bir 'politika' gerektirmektedir. Sağlık politikaları, sadece sağlık hizmetlerini kapsayan dar anlamıyla değil, doğrudan ve dolaylı olarak sosyoekonomik, sosyokültürel ve çevresel öğeleri barındıran geniş anlamı ile ele alınmalıdır. $\mathrm{Bu}$ geniş anlamıyla sağlık politikalarında devlet yaklaşımının ön plana çıtı̆̆ı söylenebilir. Sağlık hizmetleri kendine has özellikleri özelinde piyasa başarısızlıkları ile ilisskilendirilmekte ve bu durum da devlet müdahalesini gerekli k1lmaktadır. ${ }^{1}$ 1980'lerden itibaren Avrupa'da egemen olmaya başlayan neoliberal politikalar, yol açtığ 1 küreselleşme ile sermayenin ve malların serbest dolaşımını getirmiş, teknolojik gelişme paralelinde hızla yayılan neoliberal uygulamalar kamu iktisadi teşebbüslerini özelleştirme, kamu hizmetleri için ayrılan bütçenin azaltılması gibi sonuçlar doğurmuştur. $^{2}$

Ülkelerin sağllk sistemleri de bu politikalardan etkilenmiş ve ülkeler tarafindan sağlık hizmet sunumu ve hizmet finansmanı gibi hususlarda neoliberal politikalar yön gösterici olmuştur. Sağlık sistemleri dinamik bir yapıya sahip olup, 'en iyi sağlık sistemi' diye bir tanım yapmak mümkün olmadığ 1 gibi, sürekli aynı sağlık sistemi içerisinde bulunmak da doğru olmayabilir. Ülkelerin kültür, ekonomik yap1, tarihsel gelişim, ideolojik arka plan ve hayat tarzlarına göre değişen sağlık sistemleri için bu özelliklere uygun olarak geliştirilen sağlık politikalarının toplumdaki ișlerliğinin daha yüksek ve uygulanabilir olacağı belirtilmiştir. ${ }^{3}$ Dolayısıyla farklı koşullarda şekillenen sağlık sistemlerinin, karşılaştıkları krizlere gösterdikleri tepkiler de farklılaşmaktadır.

$\mathrm{Bu}$ bağlamda bütün dünyayı etkisi altına alan COVID-19 pandemisi, birçok ülkeyi sağlık politikalarını sorgulamaya ve gözden geçirmeye mecbur bırakmıştır; sağlık sistemlerinin yapısı, sağlık personeli sayısı, yoğun bakım yatak sayıları, solunum cihazları, tıbbi sarf malzemeler ve sosyal sigortaların kapsamları bunlardan bir kısmıdır. ${ }^{2}$ Bir diğer sorunsa bu süreçte daha önemli hale gelen maskeler, eldivenler, siperlikler ve koruyucu tulumlar gibi malzemelere ulaşımda yaşanan zorluklardır. Ülkelerin bu malzemeleri kısa sürede ve yeterli miktarda temin için üretim kapasiteleri yetmezken, diğer ülkelerden de bu ihtiyaçları temin etmek pandemi sürecinde kolay olmamıştır. Dolayısıyla ülkelerin sağlik sistemleri pandemi sürecinde ciddi bir sınav vermek durumunda kalmıştır.

Tüm devletlerde olduğu gibi Türkiye'de de Sağlık Bakanlığı pandemi sürecini en az vaka ile yönetmek, vakalara en hızlı şekilde cevap verebilmek ve sağlık sisteminde oluşabilecek krizlerin önüne geçebilmek adına birtakım politikalar geliştirmiştir. Pandemi süreciyle birlikte yeni birçok önlem ve terim aniden hayatımıza giriş yapmıştır. Sokağa çıkma yasakları, iller arası seyahat yasakları, karantina önlemleri, sosyal mesafe, maske, filyasyon, 'temaslı' takibi bunlardan bir kısmıdır. Bu çalışmada Türkiye'nin salgın yönetme sürecinde gerçekleştirdiği politikalara değinilecek, bu politikalar ABD, Çin ve Fransa'nın sağlık sistemleri ve salgın politikalarıyla karşılaştırılacak ve son olarak da COVID-19 salgını gibi benzer salgınlarla karşılaşılması halinde önceden alınabilecek tedbirlerden ve bu tedbirlere ilişkin politika önerilerinden

bahsedilecektir.

\section{TÜRKIYE'DE SAĞLIK SİSTEMI VE COVID-19 POLITIKKALARI}

Türkiye Cumhuriyeti Sağlı Bakanlığ sağlık göstergelerini iyileştirmek, eşit, hakkaniyetli, erişimi finansal ve fiziksel olarak mümkün k1lan, mali olarak da sürdürülebilir bir sağlık sistemi oluşturmak amacıyla sağlı sistemi içerisinde reform 
olarak da adlandırılan bir değişim sürecini başlatıp, 'Sağlıkta Dönüşüm Programı' (SDP) olarak adlandırılan bu süreç dahilinde 2003'ten itibaren sistem içerisinde köklü değişiklikler yapmıştır. SDP ile birlikte sağlık hizmetlerinin sunumunda aktif rol alan kamu-özel sektör dengesi kurulması bağlamı ve sağlık hizmetlerinin finansman yapısında, hizmet sunumu ve organizasyonda reformlar yapılmıştır. ${ }^{4}$

Birinci basamak sağlık hizmetleri SDP kapsamında getirilen yeniliklerden olan Aile hekimliği sistemi ile gerçekleştirilmektedir. Aile hekimliği sistemi ile birinci basamak sağlık hizmetlerinin güçlendirilmesi ve kişinin doğumundan ölümüne kadar sağl1k kayıtlarının tutulabilmesi, anne-çocuk sağ lı̆ 1 takibinin yapılabilmesi ve en önemlisi de sevk zincirinin birinci basamağını oluşturma amaçlanmıştır. $^{5}$ Türkiye'de 2018 y1lı itibariyle 26.252 aile hekimliği, 7.979 aile sağlığ1 merkezi, 776 toplum sağlığ1 merkezi bulunmaktadır. Aile hekimliği birimi başına düşen nüfusun 2018 verilerine göre Türkiye ortalaması 3.124 'tür. $^{6}$

Türkiye'de ikinci ve üçüncü basamak sağlık hizmetleri, Sağlık Bakanlığı hastaneleri, üniversite hastaneleri ve özel hastaneler aracılığıyla sunulmaktadır. 2018 Sağlık İstatistikleri Yıllığı'na göre 889 Sağlık Bakanlığ1 Hastanesi, 68 üniversite hastanesi ve 577 özel hastane olmak üzere toplamda 1.534 hastane bulunmaktadir. Yine 2018 yilı istatistiklerine göre toplamda 231.913 hasta yatağının 139.651'i Sağlık Bakanlığı'na bağlı hastanelere, 42.066's1 üniversite hastaneleri ve 50.196's1 özel hastanelere aittir. 2017 yılı istatistiklerine göre 10.000 kişiye düşen hastane yatak sayıs1 OECD ortalamas1 46,5 iken Türkiye ortalaması 28,3'tür. ${ }^{6}$

Türkiye'de (2018) 16.086's1 Sağl1k Bakanlığ1 hastaneleri, 6.039'u üniversite hastaneleri ve 15.973 özel hastanelerde olmak üzere toplam 38.098 yoğun bakım yatağı bulunmaktadır. Türkiye'nin yatak sayılarında meydana gelen artışta SDP ile sağlık sistemine giren Kamu Özel İşbirliği modeli ile gerçekleştirilen şehir hastanelerinin rolü bulunmaktadır. Türkiye'de 2018 yılı verilerine göre 91.559 hekim ve 126.891 hemşire çalışmaktadır. Her 100.000 kişiye düşen toplam hekim sayısı, Türkiye'de 187, OECD ülkelerinde 348 ve $\mathrm{AB}$ üyesi ülkelerde 371 'dir. 100.000 kişiye düşen hemşire sayısı Türkiye'de 301, OECD ülkelerinde 938, AB üyesi ülkelerde 841'dir. ${ }^{6}$

Sağlık sistemlerinin gücü ve talebe cevap verebilirliği hakkında fikir veren, ülkeler arasında kıyaslamalarda oldukça fazla kullanılan bu istatistikler pandemi döneminde daha çok ön plana çıkmıştır. 31 Aralık 2019'da Çin'in Wuhan eyaletinde etiyolojisi bilinmeyen pnömoni vakaları ile başlayan bu süreç, mart ayında bu vakaların 100'ün üzerinde ülkeye yayılmasıyla devam etmiştir. Türkiye'de ise, 11 Mart 2020'de ilk COVID-19 vakası Sağlı Bakanı Dr. Fahrettin KOCA tarafından açıklanmıştır. ${ }^{7}$

Türkiye'de hükümet COVID-19 pandemisi ile mücadele etmek için farklı kanallardan bir dizi önlem almıştır. Özellikle ilk onaylanmış vakaların öğrenildiği Çin, Japonya, Güney Kore gibi ülkelerle, ilişkilerde kısmi kapanış ve kısıtlamalar yoluna gidilmiştir. Bunun yanı sıra reel sektöre ve düşük gelir grubuna yönelik 35 milyar dolarlık Ekonomik İstikrar Kalkanı paketi hazırlayarak, bu grupların salgından en az etkilenmesi amaçlanmıştır. ${ }^{8}$

Türkiye tüm dünyadaki gelişmeleri yakından takip etmiş ve 10 Ocak 2020'de enfeksiyon, mikrobiyoloji, viroloji, göğüs hastalıkları, acil tıp, yoğun bakım, halk sağlığı uzmanı akademisyenlerden oluşan 31 kişiden oluşan bir Koronavirüs Bilimsel Danışma Kurulu (Bilim Kurulu) oluşturulmuş; kurul hastalıkla ilgili gerekli tedavi protokolleri hazırlamak, raporlama yapmak alınacak tedbirlerle ilgili görüş bildirmek ve hastalığı yakından takip etmek gibi görevler edinmiştir. ${ }^{7}$ Türkiye'de de ilk vakaların görülmeye başlandığı tarihten itibaren Kurulun ülkede bilinirliği artmış, ana haber bültenlerinde kurulun toplantıları ve alınan kararlar yer almaya başlamıştır. Bilim Kurulu üyeleri çeşitli programlara ve haber bültenlerine konuk olarak merak edilen hususlarda halk1 bilgilendirmeye çalışmışlardır. Kurul üyelerinin sayısı ve uzmanlık alanları ilerleyen aylarda değişiklik 
göstererek sosyal bilimcilerin de katılımıyla büyümüştür.

Sağlık Bakanlığı'nda salgın için Bilim Kurulu oluşturulması ile başlayan süreçte bir SARS-CoV-2 Enfeksiyonu (COVID-19) rehberi de yayınlamıştır ve gerekli olduğu durumlarda güncellenmeye devam edilmiştir. $\mathrm{Bu}$ süreçte broşür, salgın rehberi, normalleşme sürecine ilişkin işletme ve kurumların alması gereken önlemleri içeren yayınlar Sağlık Bakanlı̆̆g'nın web sitesinde yayınlanmaya devam etmiştir. Ayrıca vaka sayıları ve COVID-19 ile ilgili bilgilendirmeler için yine Sağlık Bakanlığı resmî internet sitesinden (https://covid19.saglik.gov.tr) günlük olarak vaka takibi yapılabilmektedir ve ilgili yayınlar ve bilgilendirme metinlerine ulaşılabilmektedir.

Pandemi ile mücadelede öne çıkan sorunlardan biri sigortaların kapsayıcılığ sigortalı birey sayıdır. Pandemi döneminde T.C. Cumhurbaşkanlığı tarafından yayınlanan kararnameye göre salgın önlemleri dahilinde sosyal sigortası olup olmadiğına bakılmadan tüm kişiler; kullanilan koruyucu ekipmandan, testler, kitler ve tedavi ilaçlarından ücretsiz yararlanabilmektedir. ${ }^{9}$ Söz konusu hastalık bulaşıcı bir halk sağlığı problemi olduğu için böyle bir adımın atılmasını gerekli kilmaktadir.

Pandemi döneminde k1sa sürede inşası tamamlanan hastaneler ise, hastalara müdahale etmeyi kolaylaştırıp sistemin kilitlenmesinin önüne geçmiştir. $\mathrm{Bu}$ hastaneler aynı zamanda yatay mimari ile inşa edilmiş acil durum hastaneleri olmasının yanında, hasta yatak sayılarını artırmış ve hasta odalarının istendiğinde yoğun bakım odasına dönüşmesi özelliği sayesinde bölgedeki yoğun bakım yatak sayısında kayda değer bir artışa sebep olmuştur. (örneğin; Prof. Dr. Feriha Öz Acil Durum Hastanesi ve Prof. Dr. Murat Dilmener Acil Durum Hastanesi). ${ }^{10}$

Ülkeler kriz anında kendi üretim kapasiteleri doğrultusunda bazı hamleler gerçekleştirmek için gerekli ve çeşitli adımlar atmaktadırlar. Türkiye'de de pandemi döneminde birçok ülkenin yokluğundan dolayı sıkıntı çektiği solunum cihazlarını, Sanayi ve Teknoloji Bakanlığı ile Sağlık Bakanlığ 1 koordinasyonu ve özel sektör iş birliği ile yerli solunum cihazının seri üretimine başlanmasıyla temin ettiği görülmüştür. ${ }^{11}$

Ülkeler pandemi sürecinde kontrolü sağlama ve bilgilendirme amacıyla mobil cihazlar için farklı uygulamalar geliştirmişlerdir. Türkiye'de de Sağlık Bakanlığı vatandaşların çevrelerindeki riski kontrol etme ve sağlıklarını takip edebilmeleri amaciyla bir mobil uygulama hizmete sunmuştur. $\mathrm{Bu}$ uygulama ayrica hastaların anlık takibini mümkün kılan HES kodu uygulamasinın da eklenmesiyle güncellenmiştir. HES kodunun yolculuklarda kullanımı zorunlu hale gelmiş ve daha sonra toplu kullanım alanına girişlerde de sorgulanması zorunlu olmuştur. $\mathrm{Bu}$ kodun amacı, kişilerin kimlerle yolculuk yaptığını, kimlerle temas edip aynı ortamda bulunduğunu takip ederek herhangi bir kişide hastalık tespit edildiğinde diğer kişilerin ve ailelerinin takibinin kolay bir şekilde yapılabilmesidir. Ayrıca COVID-19 testi yaptıran kişilerin sağlık kuruluşlarına gitmeden sonuçlarını öğrenebilmeleri için e-Nabız sistemi ile test sonuçlarını görebilme imkanı da tanınmıştır. ${ }^{12}$

COVID-19 vakalarının artmaya başlamasıyla Türkiye'de de peş peşe karantina önlemleri alınmaya başlanmıştır. Yurtdışı uçuşlarının durdurulması; iller arası seyahat yasakları; 65 yaş üstü ve 20 yaş altı sokağa çıkma yasağı; hafta sonu sokağa çıkma yasakları; alışveriş merkezleri, kafe ve restoranların kapatılması vb. ile kişiler arası bulaşın önüne geçilmesi amaçlanmıştır. Oluşturulan filyasyon ekipleri pozitif olan vakaların temaslı olduğu kişileri tespit etmekle görevli iken, aile hekimleri ise vakalar ve temaslıların kontrolünü sağlamaya çalışmaktadır.

Pandemi sürecinde öne çıkan bir diğer husus sosyal güvenlik sistemlerinin kapsayıcılığı olmuştur. Hala devam etmekte olan salgın süreci sonrasinda yapilacak değerlendirmelerin, sosyal güvenlik 
sistemlerinin yapılarını nasıl daha güçlü hale getirileceği üzerinde yoğunlaşması tahmin edilmektedir. $\mathrm{Bu}$ bağlamda tüm dünyada olduğu gibi Türkiye'nin de salgın karşısında sağlık sisteminin verdiği sınav devam etmektedir. Dolayısıyla pandemi sonrası sağlık sistemlerinin karşı karşıya kalacağı yük tahmin edilse de tam olarak çıkarım yapabilmek güçtür. $\mathrm{Bu}$ sebepten ötürü sürecin çok iyi analiz edilip sağlık sistemini iyileştirmeye ve güçlendirmeye yönelik politikaların yürütülmesi büyük önem arz etmektedir.

Çalışmanın ilerleyen bölümlerinde Türkiye ile birlikte örnek olarak belirlenen Çin, ABD ve Fransa sağlık sistemleri ile bu devletlerin COVID-19 politikalarına değinilecektir.

\section{ÇİN'DE SAĞLIK SİSTEMI VE COVID-19 POLITÍKALARI}

Çin Halk Cumhuriyeti'nin en yüksek karar organı Ulusal Halk Meclisi altında faaliyet gösteren Ĕgitim, Bilim, Kültür ve Halk Sağlı̆̆ Komitesi Çin'in sağlik politikalarının ana aktörü olarak öne çıkmaktadır. Komite altında, ona bağlı çalışan Ulusal Sağlık ve Aile Planlaması Komisyonu ise kendisine bağlı devlet kurumları ve birlikte faaliyet gösterdiği yerel otoritelerle sağlık sisteminin yürütülmesi ile görevlendirilmiştir. Ayrıca, Sivil Toplum Kuruluşları da yardımlar ve fonlar aracılığıyla sağlı sisteminin aktif bir parçasıdır. Çin sağlık sistemi hem hükümet hem de özel sektör kaynaklarının finanse ettiği bir halk sağlığı programına tabidir; bu program, kentlerde çalışanlar, ikamet edenler ve doğal afetler için ayrılan üç ayrı sağlık güvencesi sayesinde işlemektedir. 2009'dan beri Çin sağlık sistemi, söz konusu programa bağlı kılınarak 2013'te nüfusun \%95'inden fazlası sağlık güvencesine kavuşturulmuştur. Çin'de sağl1k sisteminin \%45'i özel sağl1k kuruluşlarından oluşmaktadır. ${ }^{13}$

Dünya Bankası'nın Dünya Sağlık Örgütü ile birlikte hazırladığı "Sağlıklı Çin: Çin'de Sağllk Reformunu Derinleştirmek" başlıklı raporda "hastane merkezli ve parçalı" olarak tanımlanan Çin sağlık sistemi 2000'li yıllarda yasalaşan reformlar ve doğumda beklenen yaşam süresinin artması ile övgü almıştır. ${ }^{14}$ Bu anlamda 31 ilde bulunan Sağlık Büroları, bu parçalı sistemin çok merkezden devamını sağlamaktadır. Çok katmanlılık sağlık sigortasına da yansımıştır: 1994 yılında Jiangsu ve Jiangxi eyaletlerinde uygulanan "Urban Employee Basic Medical Insurance" (UEBMI) bütün şirketler, sosyal gruplar/sivil toplum örgütlerinde çalışanlara yaptırılması zorunlu bir sigortadır ve 2009'da ülke genelinde uygulamaya konulan "Urban Resident Basic Medical Insurance" (URBMI) ise UEBMI kapsamı dışında kalan mukimler için İnsan Kaynakları ve Sosyal Güvence Bakanlığı tarafından sağlanan bir sigortadır. Ayrica Rural Cooperative Medical System (RCMS) Sağlık Bakanlığı tarafından sağlanıp gönüllülük esasına dayalı bir başka sigortadır ve 2013 yılı itibariyle Çin kırsalının \%95'i bu sigorta kapsamında sağlık güvencesi altında yaşamaktadır.

2003 'te SARS virüsü Çin'de yayıldığında, Pekin'de yalnızca 175 hastane vard 1 ve 70'ten fazla hastane SARS hastalarını kabul etmekle birlikte bu salgına ilişkin istatistikler, bugün COVID-19 pandemisi ile 
ilgili sahip olduğumuz istatistikler kadar net ve güvenilir değildi. ${ }^{15} 80$ 'lerdeki piyasalaşma politikalarının meyveleri henüz toplanıyordu: 1985 'te 3.4 milyon olan sağlık çalışanı sayısı 2001 'de 5.5 milyona, 2.4 milyon olan yatak sayısı 3.2 milyona çıkmıştı; ne var ki, Çin'in sağlık sistemi yeniden yapılandırma ihtiyacı ile karşı karşıyaydı. ${ }^{15}$ Sağlı sigortalarının bugünkü gelişim ve yaygınlığı kazanması SARS sonrası sağlık reformları sayesinde oldu. Devlet hastaneleri reformu ile birlikte ödeme mekanizmaları veya ücret politikaları yeniden düzenlenmiş ve sağlı sektörüne girişimcilerin yatırım yapmasını teşvik edici düzenlemeler yapılmıştır. Zira, 2003 yılında Çin Sağlık Bakanlığının yaptırdığı bir araştırmada sağlık harcamalarını karşılama imkanı olmadığ 1 için doktora gitmeyenlerin oranı, kırsal bölgelerde \% 39, metropollerde $\% 36$ olarak tespit edilmiştir. ${ }^{16}$

2010 'da \%50 olarak belirtilen kentleşme oranı sağlık reformlarını zorunlu kılan bir başka etmendir. Bu bağlamda her kent sakini temel sağlik hizmetlerine erişebilsin diye 2011 yılında sağlık sigortalarının kapsamının genişletilmesi kararı alınmış ve birincil sağlık hizmetlerinin herkese ulaşmasını sağlayacak bir sistem geliştirilmiştir. Bu çerçevede temel sağlık hizmetlerinin sunulması için genel bir paketle yerel düzeyde genişletilmiş paketler sağlık sigortalarına dahil edilip kırsal çiftçiler ve işsizler için malî yardımları içeren sağlık harcamaları eklenmiştir.

"Çin'in Chicagosu" olarak bilinen Wuhan kenti, yeni tip koronavirüs ile yüzleştiğinde aynı belirtiler ile ortaya çıkan sayısız virüsten biri olduğu sanıldı. Ancak salgın, diğer eyalet ve ülkelere yayılınca Çin hükümeti alarma geçmiştir ve 2020'nin ilk gününde et ticareti yasağıyla başlayan bir dizi önlem hayata geçirildi: 1800'ü aşkın epidemiyoloji ekibi vakaları ve onların kontakt kurdukları kişileri takip etmekle görevlendirildi; binlerce sağlık merkezi ve/veya karantina istasyonu kuruldu; devlet memurları ev ev, kapı kapı dolaşarak hastaları evlerinde izole kalmaya zorladilar; devlet, yeni teknolojilerle iz sürmeye devam ederken aynı anda bin hastaya birden hizmet verebilecek yeni hastaneler inşa edildi ve 40 binden fazla yeni sağlık çalışanı işe alındı.
İki ayı aşkın süre devam eden önlemlerin ve seyahat yasağının ardından 8 Nisan 2020'de kısıtlamalar kaldırılmaya başladı ve böylece ekonomik hayatın yeniden canlandırılması sürecine geçilmiş oldu. ${ }^{17}$

Çin Başbakanı Li Keqigang, 22 Mayıs 2020 tarihinde COVID-19 ile mücadeleyi iş güvencesi sağlayarak ve istikrarlı endüstriyi koruyarak, ayrıca tedarik zincirinin sağlıklı işleyişini sağlayarak ve halkın iş ve yaşam önceliğini koruyarak ve son olarak, besin ve enerji güvenliğini sağlama suretiyle; ayrıca, Çin hükümetinin beş düzeyli (eyalet, il, ilçe, belde, köy) idari bölümlenmesinde en altta yer alanların iyi işleyiş̧ini sağlama yoluyla sürdüreceklerini açıklamıştır. Bu çerçevede, yıllık malî açıktaki artışı göze alarak 141 milyar dolar (¥1 trilyon) fon COVID-19 ile mücadele için ayrılmıştır. Söz konusu bütçe doğrudan temel ihtiyaç ve istihdama destek olmak üzere yerel yönetimlere aktarılmıştır. ${ }^{18}$

Ayrıca, Çin Hükümeti'nin 2020'nin ikinci yarıyılı için 85 milyar dolar ( $¥ 605$ milyar) bütçeyi halkın temel ihtiyaçlarını karşılama, halk sağlı̆̆ 1 ve/veya enerji arzını destekleme amaciyla tahsis edeceği ifade edilmektedir. ${ }^{19}$ Ayrica COVID-19 testi ve ilgili hastane olanaklarının bedava olduğu, hastane masraflarının hastaların sağlık sigortasının karşılamadığ 1 durumlarda devlet tarafindan ödendiği belirtilmektedir. Ayrıca barınak ve otellerde şiddetli semptom göstermeyen vaka olduğunda hastaların karantina altına alındığ ve Wuhan'da hastaların \%20'sinin Fangcang denilen ve 24 saat sağlik hizmeti verilen bu barınaklarda yaşadığı ifade edilmiştir. Ayrıca Wuhan'da inşa edilmiş olan iki yeni hastane, kentteki hastaların 1/3'üne hizmet vermiştir.

Çin COVID-19 politikalarını "virüse karş1 zafer” sloganıyla savunmakta ve ABD'yi, dış politikasına uygun bir şekilde salgını kontrol altına alamamakla suçlamaktadır. Bununla birlikte, iş birliği ve dayanışma kavramlarını öne çıkararak Avrupa ve Orta Doğu ülkeleri ile COVID-19 salgını ile ortak mücadelede, çok sayıda tıbbî malzeme ve personeli İtalya, Bulgaristan, Sirbistan, Irak ve İran'a kadar ulaştırmıştır.

2003 'te SARS virüsü yayıldığında Çin'in dünyaya bilgi paylaşımı yapmakta çok geç 
kaldığ1 ve ilk vakanın 2002'nin Kasım ayında görülmesine karşın Dünya Sağlık Örgütü'ne 2003'ün Şubat ayı bildirim yapıldığg ifade edilmektedir. Ancak COVID19 pandemisi sırasında Çin Hükümeti daha hızlı ve etkin bir şekilde müdahale edebildi. Hastalıkla ilgili bilgiler Dünya Sağlık Örgütü ve yurtdışında ilgili kurumlarla paylaşılmıştır. Ayrıca SARS virüsü sırasında Çin toplumunda paniğin yayılmasına engel olunamazken COVID-19 salgınını önlemek için olağanüstü önlemlerin hızla alındığ 1 görülmüştür. Bununla birlikte, SARS salgının Çin ekonomisine etkileri 12 ila 28 milyar dolar olarak tahmin edilirken, COVID-19 pandemisinin de benzer şekilde Çin'in Gayrı Safi Yurtiçi Hasılasının \%1'ine etki edeceği ve etkilerin boyutunun salgının seyrine göre artabileceği ifade edilmektedir. ${ }^{20}$

Burada, kısaca özetlenmeye çalışılan Çin'in gelişen sağlık politikaları sayesinde
SARS salginina nazaran COVID-19 pandemisi daha hazırlıklı karşılanmıştır. Pandemi ile etkin mücadelede özellikle sağlık sigortaları halkın bütününü sağlık hizmetinden yararlandırma amacina matuf olarak birer güvence olarak, sigortalar hastane masraflarını karşılamadığ durumlarda ise devletin ödemeleri üstlendiği anlaşılmaktadır. Böylece virüsün daha hızlı yayılması önlenmiş, günlük vaka ve ölüm sayılarındaki artış kontrol altına alınmıştır. $\mathrm{Bu}$ açıdan COVID-19 salgınının ülke dışına yayılımı ile ilgili önlemleri almakta gecikmiş görünmekle birlikte, Çin'in ülke içinde düzenli ve iyi işleyen bir sağlik sisteminin varlığı, merkezî hükümetin hızlı karar alıp uygulaması ve yerel yönetimleri de destekler biçimde hızlı kaynak aktarımları sayesinde pandeminin vehametinin daha fazla büyümesinin önüne geçmiştir.

\section{ABD'DE SAĞLIK SİSTEMI VE COVID-19 POLITIKALARI}

1948’de Birleşmiş Milletler, İnsan Hakları Evrensel Bildirgesi'ni ilan ettiğinde insanlık ailesini doğuştan gelen, devredilmez haklarda eşitlemişti. Bildirgenin 25. maddesi "herkesin kendisinin ve ailesinin sağlık ve refahı için beslenme, giyinme, barınma ve tıbbî bakım hakkı" olduğunu belirtir, ne var ki Amerika Birleşik Devletleri sağlik sektöründe 'piyasa yaklaşımını' benimsemiş ülkelerden biridir. Bugün, ABD'de çok sayıda kişinin sağlık güvencesinden yoksun olduğu bilinmektedir. Ülkede ilk COVID-19 vakas1 20 Ocak 2020 tarihinde kayda geçerken aynı gün ilk vakayı bildirmiş olan Güney Kore ile arasında vakaların hızla yayılmasını önleme hususunda bir uçurum göze çarpmaktadır. 17 Mart 2020'de ABD'de henüz 25000 kişiye COVID-19 testi yapılmışken Güney Kore'de 274000 kişiye test yapılmıştı. Bu bağlamda, bu kısımda ABD'nin sağlık sistemine göz atılacak, COVID-19 politikaları genel hatları ile değerlendirilmeye çalışılacaktır.

$\mathrm{ABD}, \mathrm{OECD}$ ülkeleri içinde sağlık sistemi ve buna bağlı olarak COVID-19 ile mücadele konusunda eşitsiz koşulların en ağır şekilde tecrübe edildiği ülkelerden biri olarak göze çarpıyor: "Denetimsiz pandemi, resesyon ve güvencesiz halk" üç temel problem olarak ifade edilirken, nüfusun yaklaşık yüzde 10'u sağl1k güvencesinden yoksundur ve yaklaşık yarısının sigortası çalıştığ 1 iş yeri tarafından sağlanmıştır. $^{21}$ ABD halkının \%60'ının geleceği güvencesizdir. 32 milyon Amerikalı pandeminin doğrudan sonuçlarına maruz kalmıştır ve işsizlik oranının giderek arttığı belirtilmiştir. $^{21}$ Pandemi sirasında artan işsizlik problemine karşı tüm ülkeler çeşitli önlemler alırken sorun genelde işverenler tarafindan kisa vadeli fonlama yoluyla çözülmeye çalışılmaktadır. ${ }^{22} \mathrm{Bu}$ bağlamda ABD küçük iş yerleri için 321 milyar \$ kaynak aktarımına olanak veren toplam 483 milyar \$'lık koruma programını hayata geçirmiştir. Bu program dahilinde hastaneler için 75 milyar, COVID-19 testini yaygınlaştırmak için ise 25 milyar dolar ayrilmıştır. $^{23}$

Ayrıca, "27 Mart 2020 tarihinde Başkan Trump, çeşitli iş kollarına 2 trilyon dolarlık devlet desteği vaat eden Coronavirus Aid, Relief, and Economic Security Act (CARES Act)'i imzalamış" ve Azergün'ün belirttiği gibi, "böylelikle ABD tarihindeki en büyük 
devlet desteği paketi yürürlüğe girmiştir; CARES Act kapsamında Küçük İşletmeler Yönetimi (SBA) aracılığıyla dağıtılmak üzere küçük işletmelere 376 milyar dolarlık devlet desteği ayrılmıştır."24

ABD hükümetinin resmî internet sitesinde yayımladı̆̆ 1 verilerde birçok finansal kalemin salgın ile mücadelede doğrudan kullanıldığ görülmektedir. Çalışma Bakanlığı 'yerinden edilmiş işçilere' ayrılan kaynaklar dahilinde 100 milyon dolarlık bütçenin eyaletlere ve yerel otoritelere aktarıldı ğını, 'afet kurtarma ' dahilinde ayrılmış kaynakların da istihdamı destekleme amacıyla kullanılacağını ve son olarak, yasaların eyaletlere sağladığı esneklik sayesinde işe ara vermek zorunda kalan iş yerleri ve pandemi nedeniyle işe gidemeyen işçiler için doğrudan yardım yapılabileceğini vurgulamaktadır. ${ }^{25}$

ABD'nin Gayri Safi Yurtiçi Hasılası'nın $\% 1$ 'inin COVID-19 ile mücadelede hazırlılık ve ailelerin öncelenmesi kapsamına giren yardımlar için harcandığ 1 belirtilmektedir ki bu kapsamda COVID-19 tanı kitlerinin yanı sıra teşhis, tedavi ve aşı geliştirilmesi için çalışıldı ̆̆ koruma programları için ek kaynak sağlandığı, hastalık nedeniyle işinden olanlar için iki haftalık, 3 aya kadar iş dışı kalmış olanlar için ise $2 / 3$ oranında ödeme yapıldığ 1 , ayrıca genişletilmiş işsizlik sigortası için eyaletlere ek kaynak aktarıldığı, 1,25 milyar \$ dış yardım yapıldığg açıklanmıştır. ${ }^{23}$

Elbette bu doğrudan yardımlar önemli bir etki yaratsa da COVID-19 ile mücadelede tek başına yeterli değildir. Tıpkı Çin'de olduğu gibi ABD'de de yerleşik sağlık sistemi salgın ile mücadeleyi doğrudan belirlemiştir.

ABD'de tüm yurttaşların sağlık hizmetine erişebilmesi amaciyla 1965 yılında hayata geçirilen Medicaid ve Medicare programları, bugün ülkedeki sağlık güvencelerinin temeli olup, 1979 'da ihdas edilen Sağlik ve Sosyal Hizmetler Bakanlığı (HHS) sayesinde ABD sağlık sistemi, merkezde başlatılan projelerin alt birimlere aktarılıp uygulandığ bir yapıya kavuşturulmuştur.

ABD'deki sağlık sistemi kamusal ve özel mekanizmaların kompleks bir kombinasyonu olarak tanımlanmaktadır. $\mathrm{Bu}$ bağlamda Medicare 65 yaş üstü veya engelli yurttaşları; Medicaid ise doğrudan yoksulları; öte yandan State's Children Health Insurance Program Medicaid programına dahil olmayıp düşük gelirli olan ailelerin çocuklarını ve son olarak Indian Health Service ise Amerikan yerlilerini kapsamakta olup bunların dışında ABD ordusunda görev alanlar için ayrılmış iki sağlık sigortası daha vardır. 1990'lardan beri, ABD'de 65 yaş üstü nüfusun neredeyse tamamı Medicare'e dahil edilmiştir. ${ }^{26}$ 1965 'te yoksulların majör sağlık masraflarını karşılayabilmeleri için uygulamaya konulan Medicaid, 2017'ye gelindiğinde 250 ila 500 dolarlık tüm sağlık harcamalarını karşılar hale gelmiştir. Bununla birlikte Medicaid program1, 2010'da yürürlüğe giren ve "Obama Care" olarak bilinen Affordable Care Act (ACA) programı ile birlikte, sağlık sorunlarının çözümü için "yalnızca bir başlangıç" olarak ifade edilmektedir. ${ }^{27}$

BM'nin sürdürülebilir kalkınma hedefleri arasında yer alan sağlıklı yaşam, ABD sağlık politikaları içinde sosyal devlet çerçevesinde değil, bu bağlamda yorumlanmalıdır. Sağlık sistemi özel sektöre ve piyasa dinamiklerine bağlı olmakla birlikte ABD'nin dünyada tıbbî bakıma en çok bütçe veren ülke olması kayda değerdir. OECD ülkeleri ortalaması üstünde sağlık bütçesi bulunan ülkelere, özellikle de sosyal devlet ve refah devleti olarak bilinen Kuzey Avrupa ülkelerine göre çok daha fazla sağlık harcaması yapan ABD'nin yine de COVID-19 pandemisi ile imtihanı "başarılı" olarak ifade edilmekten uzaktır. Bu bağlamda, 2010'da ABD Başkanı Barrack Obama tarafindan hayata geçirildiği için Obama Care diye anılan sağlık programı da tüm yurttaşların sağlık hizmetine erişimini sağlayamamıştır.

Peki, doğrudan malî yardımlar ve sağlık sistemine bağlı güvenceler dışında ABD'nin COVID-19 pandemisi için aldığı belli başlı önlemlerin salgına etkileri nasıl olmuştur? Bu bağlamda Abouk ve Heydari (2020) COVID19 politikalarının kişi davranışları üzerinde yaptığı doğrudan etkileri ölçtüğü araştırmada eyaletler kapsamındaki "evde kal" çağrıları; daha sınırlı/spesifik "evde kal" çağrıları; iş 
yeri kapatmalar; kalabalıklar halinde bir araya gelinmesine yönelik yasaklar; okulları kapatma, restoran-barlara kisitlama önlemleri arasında ABD'lileri evlerinde kalmaya iten en etkili önlemin eyalet kapsamındaki evde kalma çağrıları olduğunu, bundan sonra en etkili yöntemlerin iş yerlerini kapatma ve restoran-bar sinırlandırmaları olarak öne çıktığını tespit etmişlerdir. Sınırlı ve spesifik evde kalma çağrıları ile kalabalıklar halinde toplanmayı yasaklayan önlemlerin herhangi bir etkisi olmadığı görülmüştür. ${ }^{28}$

$\mathrm{Bu}$ anlamda Çin örneğinde görüldüğü gibi ABD örneğinde de sinırlı ve sert yaptırımlar içermeyen önlemler değil doğrudan-kapsamlı ve gündelik hayatı etkileyebilecek önlemlerin sonuç almada daha başarılı oldukları görülür. Buna karşı ekonomide normalleşme adımları ile birlikte "evde kal" çağrıları büyük oranda sona ermiş ya da azalmıştır. ABD'de yeni mücadele stratejilerinin doğrudan hastalıkla mücadele ve bu uğurda ulusal ve uluslararası iş birliğine odaklandığ 1 ifade edilmiştir. ABD hükümeti tarafından 16 Eylül 2020'de ilan edilen strateji belgesi aşı dağıtımında eyalet ve yerel aktör iş birliğine vurgu yapmaktadır. Dolayısıyla hastalığın yayılmasını engelleme yönünde nispeten etkili olan çağrılar ve alınan önlemlerin yerini doğrudan "tedavi" odaklı politikalara bırakacağı görülmektedir.

Sonuç olarak, ABD genelinde uygulanan malî yardımlar ve pandemi ile mücadele önlemlerinin net bir başarı yakalayamadığ söylenebilir. Ekonomide normalleşme adımı ile birlikte, bu önlemlerin yavaş yavaş yerini yeni stratejilere bırakacağı görülmektedir. ABD'nin sağllk sistemindeki sorunların etkisi ile COVID-19 pandemisinin etkileri daha da ağırlaşmaktadır. Medicaid ve Medicare gibi sağl1k güvencelerinin nüfusun geneline etki edebilmesi için yeni düzenlemelere ihtiyaç olduğu anlaşılmaktadır.

\section{FRANSA'DA SAĞLIK SISTEMİ VE COVID-19 POLITIKALARI}

Fransa'da sağlık sisteminin hem Çin hem de ABD'deki sağlık sistemlerinden oldukça farklı olduğu söylenebilir. Evvela Fransa'da sağlık politikalarının aynı anda, birbirine zıt iki karaktere sahip olduğu (merkezileşme ve bölgeselleşme) ifade edilmektedir. ${ }^{29}$ COVID19 politikaları ise, merkezî hükümetin sorumluluğunu öne çıkarmıştır. Fransa'nın sağlık sistemi, sağlık güvenceleri ülkenin bütün sakinlerine kapsamlı bir sağlık hizmeti verilmesi esasına dayanır. COVID-19 salgını ile mücadelede Fransa'da sağlik güvencelerinin olumlu etkisi Çin ve $\mathrm{ABD}$ örnekleri ile benzerlik taşımakta olup bu kısımda söz konusu sağlık sigortaları ve devletin doğrudan malî yardımları içeren COVID-19 politikalarına göz atılacaktır.

Fransa, sağlık hizmetinde OECD ülkeleri arasında ilk sıradadır ve sağlık sistemi Ulusal Sağlık Güvencesi (National Health Insuranca -NHI) ile özel sağlık sektöründeki hizmetleri kapsayan La Médicine Libérale arasında bir dengeye dayanır; Fransızlar, sağlık hizmetine erişimdeki kolaylıkla kişi başına düşen sağlık harcamalarının ABD'nin yarısından az oluşu göz önüne alındığında başarılı sayılır. $\mathrm{Bu}$ başarı, sosyal güvencenin geleneksel ve güçlü devlet rolüyle bağlantılı olarak vergi gelirlerinin sağlık sistemindeki finansal sürdürülebilirliği gerçekleştirmesi ile açıklanabilir. ${ }^{30}$ Fransız sağlık sistemini nüfusun tamamını kapsayan sağlık güvenceleri, nüfusun $\% 92$ 'sini kapsayan ana fon ile (Caisse National d'Assurance Maladie des Travailleurs Salaries - CNAM) nüfusun \%7'sini kapsayan tarımsal fonu içermektedir, ile özetleyebiliriz. Diğer küçük fonlar, kalan $\% 1$ 'lik nüfusu kapsar. 2000 yılında yürürlüğe giren Evrensel Sağlık Kapsamı (Couverture Maladie Universelle) ulusal sağlık güvencesi kapsamını çalışanlardan tüm ikamet edenlere genişletmişti. Böylece düşük oranda, ancak sayıları giderek artan güvencesiz nüfus da sağlık güvencesine kavuşturulmuştu 2017'de Fransa Gayri Safi Yurtiçi Hasılasının \%11'ine denk sağlık harcamaları ile OECD ülkeleri arasında, Almanya ile, en yüksek oranda sağlık bütçesi olan ülke olarak öne çıkan Fransa kişi başına düşen sağlık harcamalarında AB ülkeleri arasında 6.'dır. ${ }^{30}$ $\mathrm{Bu}$ bağlamda hastanelere, devlet, özel sektör, sigorta şirketleri ve dinî gruplar gibi çok çeşitli aktörler sahip olmakla birlikte sağlık 
politikalarının merkezinde yer alan ve sektörler arası sağlık planlamasından sorumlu olan Ulusal Halk Sağlığ1 Komitesi (Commité national de santé publique) 2004 yılında kurulup bugüne kadar sağlık alanına etki edebilecek bütün kararlarda bakanlıklar arası koordinasyonu, bilgi akışını sağlamakla görevli olmuştur; bu açıdan sağlık sisteminin işleyişinde güçlü bir devlet müdahalesinden söz edilebilir. ${ }^{30}$

COVID-19 salgını Fransa'yı etkisi altına aldığında söz konusu sağlık sistemindeki istikrarın olumlu etkilerinin görüldüğü, ne var ki merkezî ve güçlü otoritenin salgını kontrol altına almakta yetersiz kaldığ ifade edilmelidir. 6 Mart 2020'de "virüs ile savaş" stratejisi kapsamında, Paris ve çevresi için Beyaz Plan (Plan Blanc) olarak ifade edilen bir mücadele programı açıklanmıştır. Ancak Fransa lideri Macron'un Mart ayı boyunca objektiflere maskesiz yakalanması tepkilere yol açmış; basın, COVID-19 ile mücadeleyi genel olarak başarısız olarak yorumlamıştır. Fransa'nın başarısızlığını siyasal sistemindeki bölgeselleşmeye karşı COVID19 ile savaşta aşırı merkezî yaklaşımla açıklayan uzmanlar, Almanya'nın aksine özel laboratuvarlara tanı kiti ve test yaptırmada serbestlik tanınmamış olmasını eleştirmektedir. ${ }^{31}$ Buna rağmen, 25 Mart'ta açıklanan plan çerçevesinde Nisan 2020'de 115 milyar \$, ki Gayrı Safi Yurtiçi Hasılanın \%4'üne denktir, iş dünyası için acil kaynak aktarımı olarak sunulmuştur. 10 Mart 2020'den beri COVID-19 Bilim Konseyi de tıp ve sosyal bilimlerden uzmanları bir araya getirerek ve hükümetten bağımsız ve gönüllü çalışma ile önerilerini açıklamıştır. ${ }^{32}$

May1s 2020'de hükümet 100 kilometreden daha uzun yolculukları yasaklamış olup, bu seyahat kısıtlamasının uygulanışı yerel idare inisiyatifine bırakılmıştır fakat hiçbir yerel yönetici bu yasağı fiiliyata geçir(e)memiştir. Yüksek risk bölgesindeki (Paris ve çevresi) yerel otoriteler ayrıca müzelerin ve barların kapatılması önlemlerinden sorumlu olmuşlar ancak yine hiçbir yerel yönetim, bu yasağ 1 uygulamamıştır. ${ }^{33} \mathrm{Bu}$ bağlamda yerel yönetim ve merkezî hükümet arasındaki bu koordinasyonsuzluk Fransa'nın COVID-19 imtihanını başarıyla geçmesini de zorlaştırmıştır.

Fransa hem iş dünyası hem de bireyler için ekonomik destek programı açıklayan ilk Avrupa ülkesi olarak öne çıkmıştır; öyle ki, 11 milyon Fransızın maaşının \%80'inin bu süreçte devlet tarafından karşılandığı ifade edilmektedir. $^{34}$ Macron'un açıkladığ kurtarma planı içinde ekonomiye kazandirılan 460 milyar avronun yanı sira Fransiz Ulusal Meclisi turizm, otomotiv ve havacılık sektörleri için 45 milyar dolarlık ek bütçeyi onaylamıştır. ${ }^{35} 17$ Mart 2020 tarihinde açıllanan yardım paketi kapsamında 300 milyar avroluk kaynağın da küçük-orta ölçekli girişimciye iflası önlemek için ayrılacağı, 45 milyar avronun şirketlere sosyal güvence katkıları için tahsis edileceği ifade edilmiştir. Buna karşın ilerleyen aylarda 800 bin iş kaybının olacağı, toplam istihdamın $\% 2,8$ oranında azalacağ öngörülmektedir. ${ }^{35}$

Vaka sayısındaki artışlar bahar aylarında Fransa hükümetini Paris ve çevresini yüksek riskli bölge ilan ederek ek önlemler almaya itmişti: Maske takma zorunluluğunun kapalı alanlardan açık havadaki kalabalık alanlara genişletilip cezası 135 euro olarak belirlendi. ${ }^{36}$ Buna karşın Macron 11 Mayıs günü okulların ve iş yerlerinin yeniden açılması emrini vermişti. Ancak okullar yeniden açıldığında veliler çocuklarını okula gönderip göndermemekte serbest birakıldı. Eylül ayında bu serbestlik sona erdirildi ve tüm öğrencilerin eğitimlerine okulda devam etmeleri kararı alındı. "Home-schooling" ile eğitime evden devam etmek isteyen ailelerin ise yerel yönetimlerden izin almaları gerekti.

Fransa 11 yaşını aşkın çocukların okulda maske takmaları zorunlu tutarken ilkokullar maske takmanın tavsiye edilmediği, yalnızca COVID-19 semptomları gösterenlere maske bulundurulacağ öne çıktı; orta okul ve lise öğrencilerinin hem bina içinde hem de dişında maske takmaları zorunluyken öğretmenlerin de sürekli maske takmaları zorunlu tutulmuştur.

Fransa' da sağlık harcamalarının yüksek ve sağlık güvencelerinin yaygın olmasına karşın COVID-19'un yayılmasının önlenemediği ve 
bu bağlamda çeşitli eleştirilerin ortaya çıktığ görülmüştür. Örneğin harcamalar vergi değil sosyal güvenlik sistemi yoluyla şirketlerden ve onların gelirlerinden temin edilmektedir. Ayrıca hükümetin sağlık çalışanlarına şükran için işverenlere bir gün tatil ödemesi önermesi "komik" bulunmuştur. ${ }^{37}$

Normalleşme kapsamında devlet karantina süresini 14 günden 7 güne indirmiş, denetim koşullarını iyileştirme adına da 2000 yeni personeli vakaların hızlı takibi için istihdam etmiştir. $^{38}$ Ancak hiçbir çıkış stratejisi olmadan kisitlamaların kaldırılmasi ve normalleşmeye geçilmesi eleştirilmektedir. ${ }^{39}$

Sonuç olarak, Fransa, iyi yapılandırılmış sağl1k güvencelerine sahip olsa da COVID19 pandemisine özel önlemleri almakta geciktiği için vakaların hızlı artışına engel olamamıştır. Çeşitli önlemleri güçlü merkezî otorite sayesinde uygulamaya koyduğunda dahi yerel otoritelerin politikalara uyumu sağlanamamış, ayrıca normalleşme adımları çeşitli eleştirilere konu olmuştur.

\section{SONUÇ VE ÖNERİLER}

1980'lerden beri sağlıkta dönüşüm üzerine yapılan tartışmalar ve uygulanan reformlar, sosyal politika bağlamında hep gündemdedir. Küreselleşmenin getirdiği veya değiştirdiği ekonomik dinamikler, değișen ihtiyaçların da etkisiyle siyasi sistemlerin önemli bir unsuru haline gelen sağlık sektörü radikal değişimler geçirmiștir. Tüm dünyaya yayılan bu reform sürecinde temel amaç harcamaları kontrol altına alarak verimliliği artırmak olarak ifade edilse de bu amaçlar gerçekleştirilirken temel sağl1k hizmetine ulaşımdan ödün verilmeden personel ve hizmetin bölgesel dağılımında eşitliğin sağlanması göz ardı edilmemelidir.

Ülkeler daha iyi sağlık çıktıları elde etmek için daha güçlü sağlık sistemlerine ve sağlık altyapılarına ihtiyaç duymaktadırlar. Sağlık harcamalarındaki artışlar sağlık sistemlerinde tartışılan ana konu halini alsa da kaynakların verimli kullanılıp kullanılmaması da sıkça tartışılan konular arasında yer almaktadır. Sağlık harcamalarını etkileyen en önemli faktörler arasında, ülkelerin gelir düzeyleri ve sağlık sorunları yer almaktadır.

Sağlığın bireysel bir mesele olmadı ̆̆ toplumsal görev ve sorumluluk anlayışıyla herkesi kapsayan hakkaniyet ve dayanışma ilkelerine dayalı bir bakış açısıyla sunulması gerektiği fikri dünyada önem kazanmıştır. Pandemi döneminde Türkiye'de, kapsayıcılık ilkesine uygun olarak COVID-19 ile savaşta herkese yeterli sağlık hizmeti sunulması, pandemi sonrası dönemde de sürdürülmeli ve toplum temelli sağlık hizmeti çerçevesinde sağlık hizmetlerinin sunulması açısından ülkedeki anlayıș ve uygulama daha da fazla güçlendirilmelidir.

Ülkeler COVID-19 pandemisinin sebep olduğu ekonomik kriz ortamından kurtulmak için belirli senaryolar çerçevesinde geleceğe yönelik tahminler yapmaktadırlar. Mevcut belirsizlik ortamında geliştirilen tahminlerde hata olasılığ senaryolar üretmeye sebep olabilmektedir. Yararlı olması adına senaryoları önceden görmek ve belirli olasılıklar çerçevesinde gerekli adımları atmayı planlamak daha umut verici olacaktır. ${ }^{40}$

Her ülke virüse karşı benzer önlemler alsa da sağlık sistemlerinin çeşitliliği, personel sayıları, teknolojik altyapıları, hatta sosyokültürel özellikleri ve demografik yapıları önlemlere yanıt vermede farklilıklara sebep olmaktadır. Çin salgınlarla yüzleștikten sonra sağl1k politikasında reforma gitmiş, sağlı̆̆ın finansman kaynağı ve kapsayıcılığını artırma yönünde adımlar atmıştır. $\mathrm{Bu}$ anlamda hayata geçirilen reformlar kırsal nüfusun \%95'inden fazlasını sağlık güvencesine kavuşturmuştur.

Çin gelişen sağlık politikası çerçevesinde COVID-19 salgını ile mücadele ederken, 21. yüzyıl tecrübesi ve sağlık hizmet sunumunun kapsayıcılığı ile ön plana çıkmıştır. Gerekli önlemlerin sağlık politikası açısından alındığı ve ekonomik yansımalarının da planlanarak, pandemiyle mücadelenin seyrinin geniş bir yelpazeye dönüştürüldüğü belirtilebilir.

ABD pandemiyle ani bir şekilde karşı karşıya kalmıştır ve onun yayılmasına engel 
olamamış/yayılma hızını kesememişti. Piyasa ekonomisi çerçevesinde sağlık hizmetlerinin sunumunun daha çok özel sektöre bırakıldığı ABD'de, nüfusun yaklaşık \%10'unun sağlık güvencesinden yoksun olduğu bilinmektedir. Salgın gibi olağanüstü koşulların olsun ya da olmasın vatandaşların sağlık güvencesinden yoksun olmaları sağlık koşullarının gelişmesi açısından olumsuzdur. Salgın göstermiştir ki, sağlık politikası ve uygulamalarının devletin sorumluluğu ve kapsayıcılığında olduğunda salgınla daha etkili mücadele edilmektedir.

ABD'nin içinde bulunduğu ekonomik durgunluk ve salgındaki denetimsizlik, sağlik güvencesinden yoksun halk ile birleştirilince, ülkenin genel olarak COVID-19 mücadelesi başarısız görülebilir. Fransa, vatandaşlarının tamamına sunduğu sağlık güvencesi ile bu alandaki kapsayıcılığını göstermekle birlikte genel olarak sağlık sisteminin işleyişinden devletin sorumlu ve müdahil olduğu sağlik politikası ancak yerel yönetimler ve merkezî hükümet arasındaki uyumla başarıya ulaşır. Merkezi hükümetin pandeminin yayılmasını önlemek için aldığı tedbirleri yerel yönetimin uygulamada gecikmesi ya da uygulamamasi, bu mücadeledeki başarıyı olumsuz yönde etkilemiştir. Ekonomik önlemlere rağmen, işgücü kaybı, istihdamda azalma kaçınılmaz olarak gerçekleşmiştir. Her ne kadar Fransa iyi yapılandırılmış bir sağlık güvencesine sahipse de merkezi hükümetin önlemlerinin, güçlü bir idare sergilenememesi neticesinde, pandemi ile mücadelede olumsuz bir etki yarattı̆̆ söylenebilir.

Türkiye'de sağlık güvencesi kapsayıcılığı, bu süreçte COVID-19 için genişletilmiş ve tüm vatandaşların tedavi hizmetlerine ulaşabilme imkanı sağlanmıştır. Gerekli tıbbi malzeme temininde yaşanan zorluklara karşın, kendi içinde üretim yapmaya ve bu malzemelere yeterli ulaşımın sağlanması için çaba sarf edilmiştir.

Sonuç olarak, tüm dünyayı halen etkilemekte olan COVID-19 pandemisi, ülkelerin sağlık sistemlerini ve politikalarını yeniden gözden geçirme, geleceğe yönelik gerekli tedbirlerin alma firsatları sunmaktadir.

$\mathrm{Bu}$ çalışma çerçevesinde incelenen ülkelerin COVID-19 politikalarına ilişkin şu sonuçlara varılabilir:

- Ülkelerin sağlık güvencelerinde, Türkiye, Çin ve Fransa'nın yeterli bir düzeyde kapsayıcılık sunduğu ancak ABD'nin yeterli düzeyde kapsayıcı olmadı̆̆ belirtilmelidir.

- Ekonomik önlemlerin tüm ülkeler tarafından özel imkanlar dahilinde alındığg ama sadece bu önlemlerin hem sağlık hizmetleri hem de ekonomik göstergeler için yeterli olmadığı vurgulanabilir.

- Sağlik hizmetlerinin sunumu için Türkiye'nin, Çin'in ve Fransa'nın imkanlarının yeterli olduğu ancak ABD'nin, sağlık güvencesinden yoksun nüfusun fazlalığı $(\% 10)$ nedeniyle sağlık hizmeti sunumu açısından "iyi" seviyede olmadığı anlaşılmaktadır.

- Devletin sağlik hizmeti sunumuna müdahalesi ve yönetiminin önemi tekrar gündeme gelmiş ve sağlik hizmetinin sosyal devlet anlayışı gereği bir devlet politikası olması gerekliliği bir kez daha önemli hale gelmiştir.
1. İleri, H, Seçer, B. ve Ertas, H. (2016). "Sağlık Politikası Kavramı ve Türkiye'de Sağlık Politikalarının İncelenmesi”. Selçuk Üniversitesi Sosyal ve Teknik Araștırmalar Dergisi, (12), 176-186

2. Altınkaya, Z. (2020). "2020 Koronavirus Pandemisinde Avrupa Birliği Sağlı Politikaları ve Neoliberalizm: İtalya Örneği”. Yalova Sosyal Bilimler Dergisi, 10 (20), 1-31.

3. Beyatll, H.Z. (2017). Hastane ve Sağlık İşletmeleri Yönetimi. Ankara: Nobel Akademik Yayıncılık Eğitim ve Danışmanlık Tic. LTD. ŞTí.
4. T.C. Sağlık Bakanlığı. (2012). "Türkiye Sağlıkta Dönüşüm Programı Değerlendirme Raporu (2003-2011)". Erişim adresi: https://sbu.saglik.gov.tr/Ekutuphane/Yayin/453 (Erişim tarihi:10.15.2020).

5. T.C. Sağlık Bakanlığı. (2008). "Türkiye Sağlıkta Dönüşüm Programı İlerleme Raporu". Erișim adresi: https://sbu.saglik.gov.tr/Ekutuphane/kitaplar/turkiyeSDP.pdf (Erișim tarihi: 10.15.2020).

6. T.C. Sağlık Bakanlığ 1 Sağlık Bilgi Sistemleri Genel Müdürlüğü. (2019). "Sağlık İstatistikleri Y1llığı 2018”. Erişim 
adresi:https://dosyasb.saglik.gov.tr/Eklenti/36134,siy2018trpdf. pdf? (Erişim tarihi:10.05.2020).

7. T.C. Sağlık Bakanlığı Halk Sağlığı Genel Müdürlüğü. (2020). "COVID-19 (SARS-CoV-2 Enfeksiyonu) Rehberi”. Ankara.

8. Yesilyurt, E.F, Turk, Y. (2020). Turkey's relief package against virus hits \$35B. https://www.aa.com.tr/en/economy/turkey-srelief-package-against-virus-hits-35b/1839854/(Erişim tarihi: 19.05.2020)

9. T.C. Resmi Gazete. (2020). Cumhurbaşkanı Kararı. Karar Sayıs1: 2399, Say1: 31099, 14/04/2020.

10. TRT Haber. (2020). “45 gün içerisinde Türkiye’ye yeni hastaneler kazandırıldı". Erişim adresi: https://www.trthaber.com/haber/gundem/45-gun-icindeturkiyeye-yeni-hastaneler-kazandirildi-488828.html, (Erişim tarihi: 19.09.2020).

11. TRT Haber. (2020). “Cumhurbaşkanı Erdoğan'dan Yerli Solunum Cihazı Müjdesi”. Erișim adresi: https://www.trthaber.com/haber/gundem/cumhurbaskanierdogandan-yerli-solunum-cihazi-mujdesi-471631.html, (Erişim Tarihi: 19.09.2020).

12. T.C. Sağlık Bakanlı̆̆ı. (2020). "Hayat Eve Sı̆̆ar”. Erişim adresi: https://hayatevesigar.saglik.gov.tr/hes.html. (Erişim tarihi: 19.09.2020).

13. Mills, A. and Tangcharoensathien, V. (Ed.) (2015). "People's Republic of China Health System Review.Health System in Transition". 55 (7). 5 Erişim https://iris.wpro.who.int/bitstream/handle/10665.1/11408/97892 90617280_eng.pdf;jsessionid=9D2E0398D69E2CD263CF56D 229F50EC0? sequence=1 (Erişim tarihi: 15.9.2020).

14. Dünya Bankası. (2019). "Healthy China:Deepening Health Reform in China”. Erişim adresi:https://openknowledge.worldbank.org/handle/10986/314 58 (Erişim tarihi: 14.09.2020).

15. Liu, Y. (2004). "China's Public Health-care System: Facing the Challenges. Bulletin of the World Health Organisation”. 82 (7), 532-538.

16. Ma, S. and Sood, N. (2008). "A Comparison of the Health Systems in China and India. Rand Center for Asia Pacific Policy. RAND Corporation". Erişim adresi: https://www.rand.org/content/dam/rand/pubs/occasional_papers /2008/RAND_OP212.pdf (Erişim tarihi: 14.09.2020).

17. AlTakarli, N.S. (2020). "China's Response to the COVID-19 Outbreak: A Model for Epidemic Preparedness and Management". Dubai Med J, 3, 44-49.

18. The Conversation. (2020). “China's New Coronavirus Recovery Srategy Explained”. Erişim adresi: https://www.eulerhermes.com/tr_TR/hakkimizda/sonhaberler/cin-de-koronavirus-salgini.html (Erişim tarihi: 15.09.2020)

19. Global Times. (2020). "China Moves to Block COVID-19 Resurgence With Detailed Health Policy". Erişim adresi: https://www.globaltimes.cn/content/1189144.shtml (Erişim tarihi: 15.09.2020).

20. Euler Hermes. (2020). "Çin'de Korona Virüs Salgını”. Erişim adresi: www.eulerhermes.com/tr_TR/hakkimizda/sonhaberler/cin-de-koronavirus-salgini.html (Erişim tarihi: 14.09.20209).

21. Elshaug, A. (2020). "Pandemic Letter From Amerika: How the US handling of Covid-19 provides the starkest warning for us all”. Erişim adresi: https://theconversation.com/pandemicletter-from-america-how-the-us-handling-of-covid-19-providesthe-starkest-warning-for-us-all-144357 (Erişim tarihi: 20.09.2020).
22. Rothwell, J. and Drie, H.V. (2020). "The Effect of Covid-19 and Disease Suppression Policies on Labor Markets: A Preliminary Analysis of Data". Erişim adresi: https://www.brookings.edu/research/the-effect-of-covid-19and-disease-suppression-policies-on-labor-markets-apreliminary-analysis-of-the-data/ (Erişim tarihi: 22.09.2020).

23. Internatıonal Money Fund. (2020). "Covid-19 Policy Responses". Erişim adresi: www.imf.org/en/Topics/imf-andcovid19/Policy-Responses-to-COVID-19 (Erişim tarihi: 22.09.2020).

24. Azergün, N. (2020). "Bilgi Notu: ABD'de COVID-19 ve Küçük İşletmelere Yönelik Alınan Ekonomik Önlemler”. Erişim adresi: www.gif.org.tr/files/COVIDSmallBusiness.pdf, (Erişim tarihi: 23.09.2020).

25. U. S. Department of Labour. (2020). "Coronavirus Resources". Erişim adresi: https://www.dol.gov/coronavirus (Erişim tarihi: 24.09.2020).

26. Sato, R, Grivoyannis, E, Byrne, B. and Lian, C. (1997). Health Care Systems in Japan and the United States: A Simulation Study and Policy Analysis. Springer Science+Business Media. New York

27. Peterson, M.A. (2011). "Rethinking Conceptual Frameworks: Obama and the Unique Opportunity for Health Care Reform". Jounal of Health Politics. Policy and Law, 36 (3), 429-436. DOI 10.1215/03616878-1271054.

28. Abouk, R. and Heydarı, B. (2020). "The Immediate Effect of Covid-19 Policies on Social Distancing Behaviour in the United States". Erişim adresi: https://www.medrxiv.org/content/10.1101/2020.04.07.2005735 6v2 (Erişim tarihi: 24.09.2020).

29. Matsuda, S. (2008). "Decentralization of Health Policy Making in France". Asian Pacific Journal of Disease Management, 2 (1), 7-16

30. OECD. (2019). "State of Health in the EU: France (Country Health Profile 2019)". Erişim adresi: https://www.oecd.org/health/france-country-health-profile2019-d74dbbda-en.htm (Erişim tarihi: 09.09.2020).

31. Strategic Comments. (2020). "France's Response to Covid-19." 26 (5), 4-6 Erişim adresi: https://www.tandfonline.com/doi/abs/10.1080/13567888.2020. $1805910 \quad$ (Erişim tarihi: 05.09.2020). https://doi.org/10.1080/13567888.2020.1805910

32. Chauvin, F, Yazdanpanah, Y, Lina, B, et al. (2020). "France's Covid-19 Response: Balancing Conflicting Public Health Traditions". The Lancet 396 (10246), 219-221. Erişim adresi: https://www.thelancet.com/journals/lancet/article/PIIS01406736(20)31599-3/fulltext (Erişim tarihi: 01.09.2020). https://doi.org/10.1016/S0140-6736(20)31599-3.

33. The Local. (2020a). "Bar Closures and Local Lockdowns: What New Covid-19 Restrictions Could France Impose?”. Erişim adresi: www.thelocal.fr/20200911/bar-closures-and-travelrestrictions-what-measures-to-expect-from-frances-new-covid19-restrictions (Erişim tarihi: 15.09.2020).

34. Lichfield, J. (2020). "Coronavirus: France's 'Strange Defeat"”. Erişim adresi: https://www.politico.eu/article/coronavirusfrances-strange-defeat/ (Erişim tarihi: 14.09.2020).

35. Damiani, A. (2020). "Macron Announces National Recovery Plan of "At Least 100 Billion Euro"”. Erişim adresi: https://www.euractiv.com/section/politics/short_news/parismacron-announces-national-recovery-plan-of-at-least-e100billion/ (Erişim tarihi: 13.09.2020).

36. The New York Times. (2020). "Beaten Back, the Coronavirus Regains Strength in France 17.08.2020". Erişim adresi: https://www.nytimes.com/2020/08/17/world/europe/francecoronavirus.html (Erişim tarihi: 14.09.2020). 
37. Myant, C. (2020). "Re-looking and Revaluing Health, postCOVID in France. 15.6.2020". Erişim adresi: https://www.opendemocracy.net/en/can-europe-make-it/relooking-and-revaluing-health-post-covid-france/ (Erişim tarihi: 20.08.2020).

38. Ians. (2020). "France Cuts Self-İsolation Period From 14 Days To 7 Days 12.09.2020". Erişim adresi: https://travel.economictimes.indiatimes.com/news/destination/i nternational/france-cuts-self-isolation-period-from-14-days-to7-days/78079012 (Erişim tarihi: 20.9.2020)

39. Di, LD, Pullano, G., Sabbatini, C.E., Boëlle, P.Y. and Colizza, V. (2020). "Impact of lockdown on COVID-19 epidemic in Îlede-France and possible exit strategies. BMC Medicine". 18 (1), 240-240.

Erişim adresi:https://www.researchgate.net/publication/343307408_Im pact_of_lockdown_on_COVID-19_epidemic_in_Ile-deFrance_and_possible_exit_strategies (Erişim tarihi: 01.09.2020). doi: 10.1186/s12916-020-01698-4.

40. Köse, T. (2020). "Global Governance and Crisis Management in the Post COVID-19 World." Reflection on The Pandemic in The Future of The World. Şeker, M, Özer, A, Korkut, C. (Eds.). Turkish Academy of Science, 369-391. Ankara: Berk Grup Matbaacilık. 